\title{
Prevalence and Distribution of Multidrug-Resistant Mutations in Mycobacterium tuberculosis in Tanzania
}

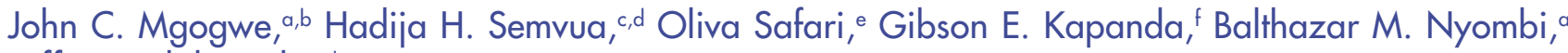 \\ Jaffu O. Chilongola $a^{a, d}$ \\ 'Department of Biochemistry and Molecular Biology, Kilimanjaro Christian Medical University College, Moshi, Tanzania; bepartment of Laboratory Diagnostics, \\ Kibong'oto Infectious Disease Hospital, Sanya Juu, Tanzania; 'Department of Pharmacy, Kilimanjaro Christian Medical University College, Moshi, Tanzania;

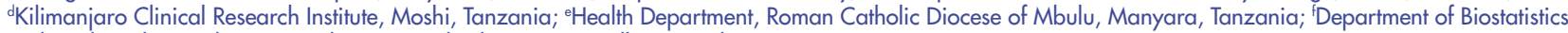 \\ and Epidemiology, Kilimanjaro Christian Medical University College, Moshi, Tanzania \\ Correspondence to John C. Mgogwe (mgogwej@yahoo.com)
}

\begin{abstract}
Background: Molecular identification of mutations resulting in multidrug-resistant tuberculosis (MDR-TB) is an important approach for improving understanding of MDR-TB epidemiology and planning for appropriate interventions. We aimed to estimate the prevalence and distribution of mutations causing MDR-TB as well as determine the gene distribution among patients previously treated for TB.

Methods: This was a cross-sectional, hospital-based study conducted from April 2017 to October 2018 at Kibong'oto Infectious Diseases Hospital (KIDH). KIDH is the national MDR-TB referral hospital. Participants were patients presumptively diagnosed with MDR-TB and referred to KIDH from district and regional hospitals across Tanzania. Sputum samples were collected and analysed using the Xpert MTB/RIF assay, direct sputum smear fluorescence microscopy, culture on Lowenstein-Jensen medium, and line probe assay using the GenoType MTBDRplus VER 2.0 system. Demographic information and mutation frequencies were reported as counts and percentages and analysed using descriptive statistics.

Results: A total of 208 (69.3\%) participants had rpoB gene mutations conferring resistance to only rifampicin; 92 (30.7\%) had rpoB, katG, and inhA mutations conferring resistance to rifampicin and isoniazid; 78 (26\%) had rpoB and katG mutations conferring resistance to rifampicin and isoniazid; and $14(4.7 \%)$ had rpoB and inhA mutations conferring resistance to rifampicin and isoniazid.

Conclusion: The mutation prevalences identified in this study indicate the most frequent mutations were the S531L mutation of the rpoB gene, the S315T1 mutation of the $k a t G$ gene, and the S315T mutation in the promoter region of the inhA gene. To control the emergence and spread of MDR-TB, drug sensitivity testing must be carried for GeneXpert-confirmed TB patients prior to initiating second-line anti-TB regimens.
\end{abstract}

\section{INTRODUCTION}

$T^{1}$ uberculosis (TB) continues to be a disease of public health importance worldwide. The emergence of multidrug-resistant TB (MDR-TB) is a serious challenge to TB control. ${ }^{1}$ MDR-TB, defined as resistance to both isoniazid and rifampicin, is a growing public health problem in resource-poor regions where adequate diagnosis and treatment are often unavailable..$^{2-5}$ The World Health Organization (WHO) report of 2018 estimates that there were 558,000 new cases of rifampicin-resistant TB in 2017, 82\% of which were MDR-TB. ${ }^{6}$ MDR-TB is estimated to affect $3.5 \%$ of patients diagnosed with TB for the first time and $20.5 \%$ of those previously treated for TB. WHO estimates that about $5 \%$ of all TB patients progress to MDR-TB, which had a peak mortal- ity rate of more than $40 \%$ in $2013 .^{7,8}$ Tanzania is among the 30 countries most affected by TB and MDR-TB, with an MDR-TB prevalence of $1.1 \%$ in 2010 . ${ }^{6,9,10}$

Resistance to anti-TB agents by Mycobacterium tuberculosis is caused by mutations in genes or the promoter regions of genes involved in drug activation or encoding drug targets. Molecular mechanisms for resistance to rifampicin are known to involve chromosomal mutations in the RNA polymerase $\beta$-subunit gene $(r p o B)$, which encodes the $\beta$ subunit of the $M$. tuberculosis RNA polymerase chain. ${ }^{11-14}$ Isoniazid is one of the most effective anti-TB drugs. The majority of the mutations responsible for high-level $M$. tuberculosis isoniazid resistance are found in the catalase peroxidase gene $(k a t G) .{ }^{15}$ Isoniazid resistance also commonly results from mutations in the 


\section{FIGURE 1. Sample Collection and Processing Flow Chart}

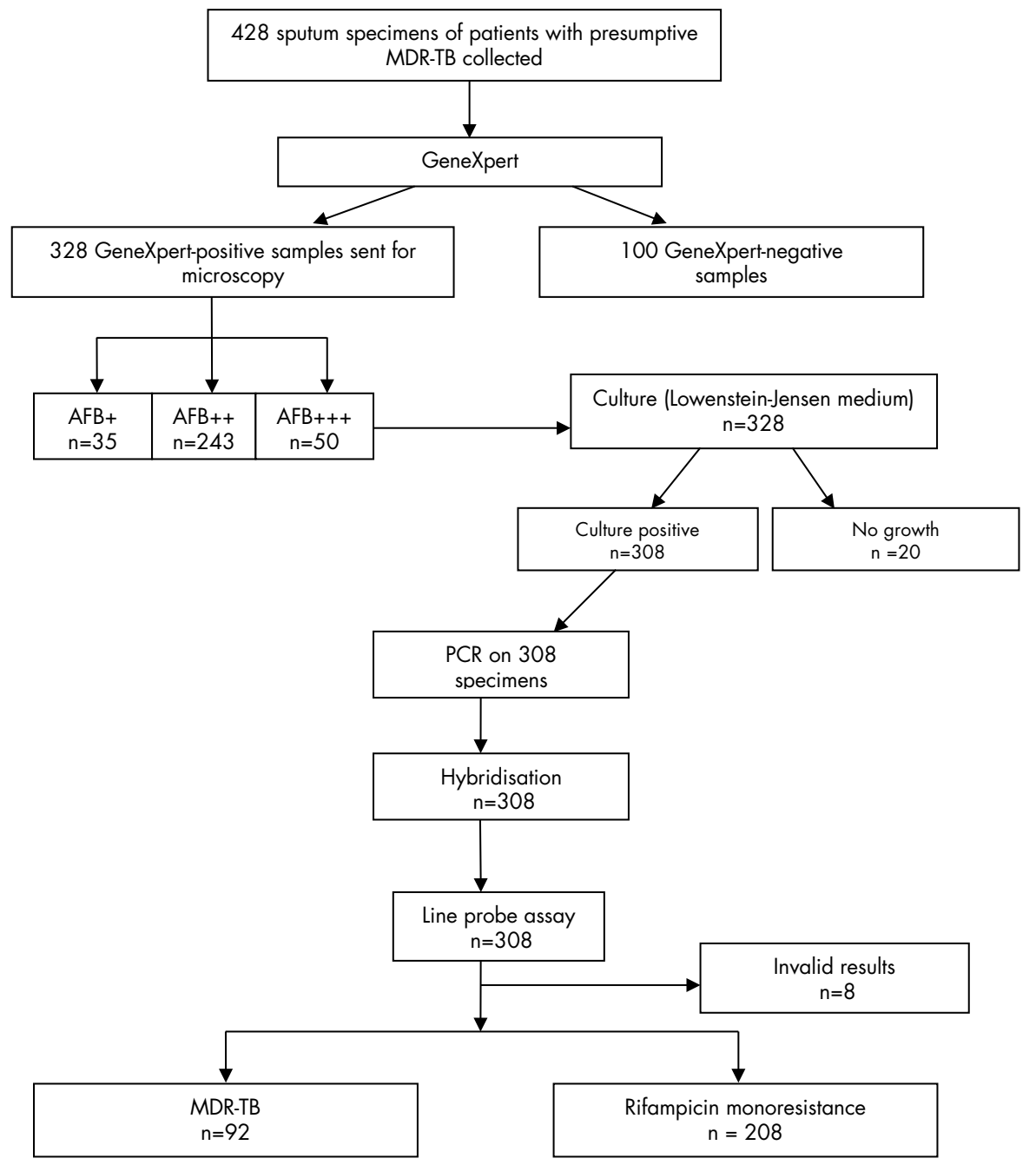

Abbreviations: AFB, acid-fast bacilli; MDR-TB, multidrug-resistant tuberculosis; PCR, polymerase chain reaction

promoter region of the enoyl acyl carrier protein reductase gene $(i n h A)^{15}$; these mutations increase inhA expression and confer low-level resistance to isoniazid. ${ }^{16}$ The lower susceptibility to isoniazid is associated with mutations in the structural region of inhA, which lower affinity to drug-NAD adducts. ${ }^{16}$

The molecular detection of $M$. tuberculosis mutations is important for the understanding of TB epidemiology, as it can help predict transmission rates and identify dominant strains, strains with enhanced capacity to spread, and strains associated with outbreaks ${ }^{17}$ and severe disease. ${ }^{18,19}$ Effective genotypic monitoring of the emergence of drug-resistant strains of M. tuberculosis is pivotal to TB control, more so than the detection of drug resistance by phenotype, which suffers from protracted identification of resistant strains. There is accumulating evidence correlating gene mutations with phenotypic resistance; however, the relevant data are sparse and inconsistent, particularly in sub-Saharan Africa where the disease burden is highest. ${ }^{18}$

This study aimed to estimate the prevalence and distribution of mutations causing MDR-TB as well as determine the gene distribution among patients previously treated for TB who presented at Kibong'oto Infectious Disease Hospital (KIDH) in Sanya Juu, Tanzania. 
TABLE 1. Sociodemographic Characteristics $(\mathrm{N}=300)$

\section{Characteristics}

n (\%)

\section{Age, years}

$\begin{array}{lc}20-30 & 85(28.3) \\ 31-40 & 101(33.7) \\ 41-50 & 82(27.3) \\ \geq 50 & 32(10.6)\end{array}$

Gender

Female

$109(36.3)$

Male

$191(63.7)$

Marital status

Single

$165(55)$

Married

$135(45)$

\section{METHODS}

\section{Design and Settings}

This was a hospital-based cross-sectional study conducted from April 2017 to October 2018 at KIDH, a national referral hospital for patients from all parts of Tanzania. KIDH is currently the country's largest referral hospital for MDR-TB management, with a dedicated 40-bed capacity in addition to separate facilities for treating drug-susceptible TB.

\section{Study Participants and Inclusion Criteria}

We enrolled referred inpatients aged 18 years and older. A structured questionnaire was administered by interviewers to collect sociodemographic information in addition to that obtained from the hospital files. We excluded admitted patients on treatment for diseases other than TB and those coming from outside of Tanzania.

\section{Sample and Data Collection}

Sputum samples were collected from each participant in a sterile Falcon tube (BD Biosciences, Bedford, MA, USA). The Xpert MTB/RIF assay (Cepheid, Sunnyvale, CA, USA) for molecular detection of MDR-TB was used to test all sputum samples. $^{20,21}$ Direct sputum smear fluorescence microscopy ${ }^{22,23}$ was used to test for acid-fast bacilli (AFB) for all enrolled patients. All AFB-positive sputum samples were cultured on the Lowenstein-Jensen (LJ) medium (HiMedia Laboratories GmbH, Einhausen, Germany). Recovered M. tuberculosis colonies from LJ medium culture-positive sputum samples were used to perform a line probe assay (LiPA) employing the GenoType MTBDRplus VER 2.0 system (Hain Lifescience GmbH, Nehren, Germany) according to the manufacturer's instructions (Figure 1). ${ }^{24}$

\section{LiPA}

M. tuberculosis DNA was extracted from recovered M. tuberculosis colonies using the GenoLyse DNA extraction kit (Hain Lifescience $\mathrm{GmbH}$ ) followed by a polymerase chain reaction sequence to amplify the rpoB gene encoding the $\beta$-subunit of RNA polymerase, the kat $G$ gene encoding for catalase peroxidase, and the promoter region of the inh $A$ gene encoding for NADH enoyl ACP reductase, for the detection of genomic mutations associated with MDR-TB. The primers and polymerase included in the MTBDRplus Ver 2.0 assay kits were used to amplify the genes, and the H37Rv quality control M. tuberculosis strain was used as the positive control. The M. tuberculosis mutations in the rроB gene associated with rifampin resistance, and those in the kat $G$ and $i n h A$ genes associated with isoniazid resistance, were interpreted and determined by the band patterns on the LiPA strips after reverse hybridisation of the gene amplificates. ${ }^{24-26}$

\section{Statistical Analysis}

Data were analysed using IBM SPSS Statistics version 20 (IBM Corp., Armonk, NY, USA). Data were summarised using frequency distributions and charts for categorical data and descriptive statistics (mean, median, standard deviation, and interquartile range) for numerical data. Chi-square tests were applied to assess patient sociodemographic and clinical characteristics associated with drug resistance, and Fisher's exact was used to calculate $P$ values when comparing small frequencies (less than 5). The mutations rates in the rpoB, kat G, and inhA genes, in relation to MDR-TB-negative and MDRTB-positive status, were also estimated.

\section{Ethical Considerations}

Ethical approval was obtained from the Kilimanjaro Christian Medical University College Research and Ethics Committee (Certificate number 2039, April 2017). Permission from $\mathrm{KIDH}$ management was obtained from the medical officer in charge. All participants consented to participate in the study voluntarily after the study was explained to them. The patients' confidentiality and privacy were strictly observed.

\section{RESULTS}

A total of 428 presumptive sputum specimens were collected from newly referred patients to KIDH. Of these, 100 tested negative for TB using Xpert MTB/RIF, and these patients were 


\section{FIGURE 2. Prevalence and Distribution of Mutations among Mycobacterium tuberculosis Isolates by Sex}

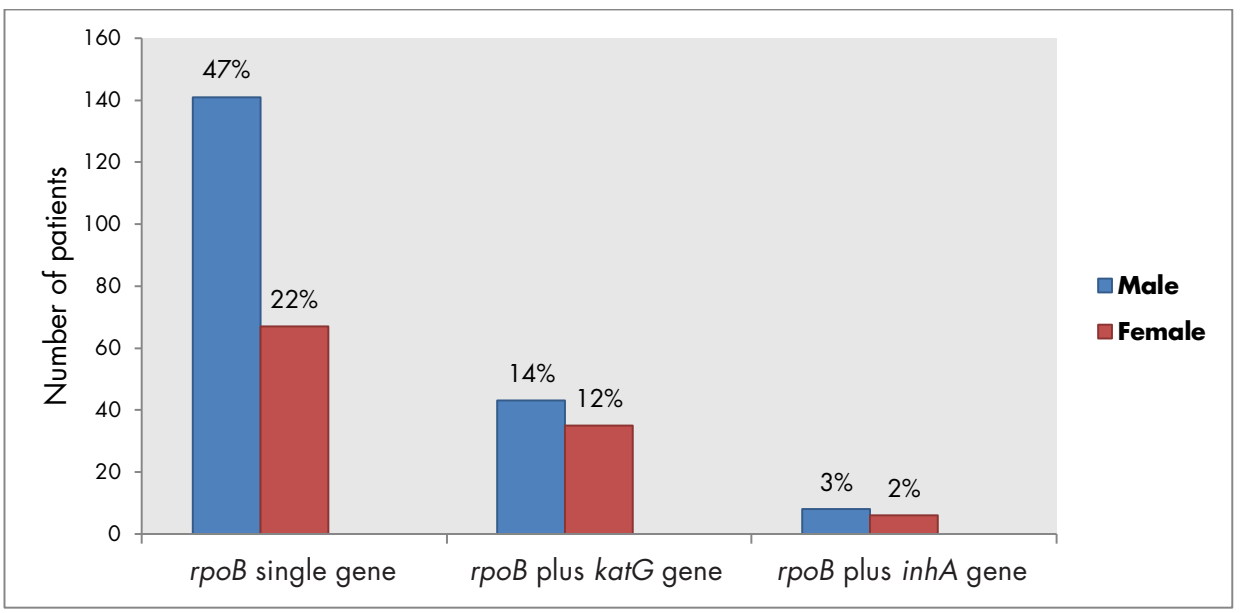

excluded from the study and treated as per routine hospital guidelines. Sputum smear fluorescence microscopy was carried out on 328 samples, which were then cultured on LJ medium. Twenty of the samples were LJ medium culture-negative, and the patients who submitted these samples were excluded and treated as per routine hospital guidelines. DNA extraction - using GenoLyse kits according to manufacturer's instructions - was performed on 308 specimens that showed growth in AFB culture. The LiPA was performed for 308 specimens, and 8 specimens returned invalid LiPA results; the patients who submitted these 8 specimens were excluded from the analysis and treated as per standard-of-care guidelines.

Out of the 300 patients recruited, 191 (63.7\%) were male, and $109(36.3 \%)$ were female. The mean patient age was $37.5 \pm 10$ years. Patients between of 20 and 40 years old were most affected by MDR-TB (Table 1). There were 208 (69.3\%) isolates that had mutations conferring resistance to only rifampicin (rifampicin-monoresistant) and $92(30.7 \%)$ isolates that had mutations conferring resistance to both rifampicin and isoniazid (multidrug-resistant [MDR] isolates) (Figure 2). The S531L mutation was observed in $182(60.7 \%)$ of the isolates. Seventy-eight $(26.0 \%)$ were found to have the katG gene mutations. Fourteen $(4.7 \%)$ isolates had solitary inh $A$ gene mutations (Table 2).

\section{Prevalence and Distribution of $M$. tuberculosis Mutations by Sex}

Among the 208 LiPA-screened patients with single rpoB gene mutations, 141 (67.8\%) were male. Among 78 (26\%) patients whose isolates had both rров and kat $G$ gene mutations, 43 $(55.1 \%)$ were male. Fourteen patients $(4.7 \%)$ had $r p o B$ and inh $A$ gene mutations, 8 ( $57.1 \%$ ) of whom were male.

\section{Rifampicin Resistance-Associated Mutations}

Rifampicin resistance-associated mutations involving the rрoB gene were the most frequently encountered mutations in this study, appearing in $208(69.3 \%)$ isolates (Table 3). The S531L (TCG $\rightarrow$ TTG) rpoB mutation was observed in 182 $(60.7 \%)$ isolates. The frequency of the S531L mutation in the $r p o B$ gene was significantly higher among rifampicin-monoresistant isolates than among MDR isolates $(P<.01)$. Mutations in the rpoB gene region encompassing codons 513 to 519 were significantly more common among non-MDR-TB isolates than among MDR-TB isolates $(P<.01)$ (Table 3$)$.

\section{Isoniazid Resistance-Associated Mutations}

The kat 3 315ACC mutation was the most common isoniazidrifampicin multidrug resistance-associated mutation identified in this study. The S315Tl katG gene mutation - with a codon change of AGC $\rightarrow$ ACC - occurred in 78 (84.8\%) of 92 MDR isolates detected. Mutations at the promoter region of the inh $A$ gene were also detected. Overall, the $315 \mathrm{ACC}$ mutation was found in $14(15.2 \%)$ of the 92 MDR isolates: 7 with the MUT1 S315T variant (TCG $\rightarrow$ TGG), 1 with the WT 315 variant, and 6 with the WT1 C15T variant (GGC $\rightarrow$ ACC) (Table 3).

\section{DISCUSSION}

The present study highlights the prevalence and distribution of MDR M. tuberculosis mutations in Tanzania. The majority patients were between 20 and 40 years old, with male patients predominating. The frequency of MDR-TB in this age group has substantial socioeconomic implications, as young adult males are an important component of the economically productive population. A high MDR-TB prevalence among young adults has an acute impact on the national economy. TB control strategies need to set specific targets for all age groups, but for this group in particular. Our findings are comparable 
TABLE 2. Prevalence and Distribution of Gene Mutations in Mycobacterium tuberculosis by Patient Characteristics $(\mathrm{N}=300)$

\begin{tabular}{|c|c|c|c|c|c|c|c|c|}
\hline \multirow[b]{3}{*}{ Characteristics } & \multicolumn{5}{|c|}{ Non-Multidrug-Resistant (n=208) } & \multicolumn{3}{|c|}{ Multidrug-Resistant (n=92) } \\
\hline & \multicolumn{5}{|c|}{ rpoB (Monoresistance) } & \multirow{2}{*}{$\begin{array}{c}\begin{array}{c}k a t G \text { and } \\
\text { rpoB }(\mathrm{n}=78)\end{array} \\
\begin{array}{c}\text { MUT1 } \\
\mathrm{n}=78(\%)^{f}\end{array}\end{array}$} & \multicolumn{2}{|c|}{$r p o B$ and inhA $(n=14)$} \\
\hline & $\begin{array}{c}\text { MUT1, } \\
\text { MUT2B, } \\
\text { (S315T1), } \\
\text { (H526D) } \\
\mathrm{n}=5 \text { (\%) }\end{array}$ & $\begin{array}{c}\text { MUT3 } \\
\text { (S531L) } \\
\mathrm{n}=182(\%)^{\mathrm{b}}\end{array}$ & $\begin{array}{c}\text { WT3 } \\
(513-517) \\
n=9(\%)^{c}\end{array}$ & $\begin{array}{c}\text { WT4 } \\
(519-519) \\
n=7(\%)^{d}\end{array}$ & $\begin{array}{c}\text { WT7, WT8 } \\
n=5 \text { (\%)e }\end{array}$ & & $\begin{array}{c}\text { MUT1 } \\
\text { n=7 (\%)g }\end{array}$ & $\begin{array}{l}\text { WT, WT I } \\
\text { n=7 (\%) }\end{array}$ \\
\hline \multicolumn{9}{|l|}{ Age } \\
\hline $20-30$ & $2(40 \%)$ & $51(28.02 \%)$ & $1(11.2 \%)$ & $2(28.57 \%)$ & $1(20 \%)$ & $24(30.7 \%)$ & $2(28.57 \%)$ & $2(28.57 \%)$ \\
\hline $31-40$ & $1(20 \%)$ & $58(31.9 \%)$ & $4(44.4 \%)$ & $2(28.57 \%)$ & $3(60 \%)$ & $28(35.9 \%)$ & $3(42.86 \%)$ & $2(28.57 \%)$ \\
\hline $41-50$ & $2(40 \%)$ & $53(29.1 \%)$ & $0(0 \%)$ & $3(42.86 \%)$ & $1(20 \%)$ & $18(23.1 \%)$ & $2(28.57 \%)$ & $3(42.86 \%)$ \\
\hline$\geq 50$ & $0(0 \%)$ & $20(0.11 \%)$ & $4(44.4 \%)$ & $0(0 \%)$ & $0(0 \%)$ & $8(10.3 \%)$ & $0(0 \%)$ & $0(0 \%)$ \\
\hline \multicolumn{9}{|l|}{ Gender } \\
\hline Female & $3(60 \%)$ & $58(31.9 \%)$ & $3(33.3 \%)$ & $3(42.86)$ & $1(20 \%)$ & $35(44.9 \%)$ & $2(28.7 \%)$ & $4(57.1 \%)$ \\
\hline Male & $2(40 \%)$ & 124 (68.1\%) & 6 (66.7\%) & $4(57.14 \%)$ & $4(80 \%)$ & 43 (55.1\%) & 5 (71.3\%) & 3 (42.9\%) \\
\hline
\end{tabular}

a-hFor each entry in the respective columns, the denominators are $5,182,9,7,5,78,7$, and 7 , respectively, which are counts for every mutation reported in a column across participant age groups and genders

with observations from previous studies in India, South Africa, and Zimbabwe, which revealed higher rates of MDR-TB among youths and young adults. ${ }^{27-29}$

We found a higher prevalence of MDR-TB among men in our study. Although the explanations regarding differences in immunity between men and women are incomplete, it is generally accepted that infectious diseases rarely affect males and females equally. ${ }^{30}$ Females exhibit a more robust immune response to antigenic challenges, such as infection and vaccination, than males. ${ }^{31}$ This is mediated largely by sex hormones, the role of which - in TB - is supported by the fact that the male disadvantage does not arise until puberty. ${ }^{30,32}$ Sex hormones have diverse effects on many immune cell types, including B cells, T cells, neutrophils, dendritic cells, macrophages, and natural killer cells. ${ }^{30}$ Other reasons for these gender differences may be related behavioural and exposure differences - including regarding social roles and risk behaviours, such as alcohol and tobacco consumption - between the sexes, which make males more likely to acquire TB. ${ }^{30,33-35}$ In this regard, our findings are contradictory to what was previously reported in Pakistan and Afghanistan, where TB has been reported to be more prevalent among women than men $^{36}$; however, our results are comparable with other studies done in other parts of the world. ${ }^{30,37-42}$ It has been reported that nearly twice as many men as women have been diagnosed with TB globally. ${ }^{43,44}$ These findings are relevant for planning different TB control strategies and programmes, especially in low-resource settings.

We found a high prevalence of rifampicin monoresistance determined by rpoB gene mutations. Drug resistance is multifactorial and - in the presence of HIV infection, for example - higher rates anti-TB drug resistance could be attributable to HIV-associated malabsorption, mismanagement of TB cases, adherence challenges and antiretroviral and anti-TB drug interaction. ${ }^{45-49}$ Rifampicin is the most vital drug for TB treatment; therefore, resistance to rifampicin 
TABLE 3. Prevalence and Distribution of Mutations, Amino Acid Changes, and Nucleotide Change in Mycobacterium tuberculosis Isolates ( $\mathrm{N}=300)$

\begin{tabular}{|c|c|c|c|c|c|c|c|c|}
\hline Gene & $\begin{array}{l}\text { Band } \\
\text { Missing } \\
\text { (WT\#)/ } \\
\text { Mutation } \\
\text { Present } \\
\text { (MUT\#) }\end{array}$ & $\begin{array}{l}\text { Mutation } \\
\text { or Codons } \\
\text { Involved }\end{array}$ & $\begin{array}{l}\text { Amino Acid } \\
\text { Change }\end{array}$ & $\begin{array}{l}\text { Nucleotide } \\
\text { Change }\end{array}$ & $\begin{array}{l}\text { Non-MDR-TB } \\
n=208\end{array}$ & $\begin{array}{c}\text { MDR-TB } \\
n=92\end{array}$ & $\begin{array}{c}\text { Fisher's } \\
\text { Exact } \\
\mathbf{X}^{2}\end{array}$ & $P$ Valu \\
\hline \multicolumn{9}{|l|}{ rpoB } \\
\hline & MUT1 & S315T1 & $\mathrm{Ser} \rightarrow \mathrm{Thr}$ & $\mathrm{AGC} \rightarrow \mathrm{ACC}$ & 2 & 0 & & - \\
\hline & MUT2B & H526D & $\mathrm{His} \rightarrow \mathrm{Asp}$ & $\mathrm{CAC} \rightarrow \mathrm{GAC}$ & 3 & 0 & & - \\
\hline & MUT3 & S531L & Ser $\rightarrow$ Leu & $\mathrm{TCG} \rightarrow \mathrm{TTG}$ & 182 & 0 & 191.48 & $<.01$ \\
\hline & WT3 & $517-519$ & Asn $\rightarrow$ Lys & $\mathrm{AAC} \rightarrow \mathrm{AAA}$ & 9 & 0 & 5.967 & .02 \\
\hline & WT4 & $513-517$ & $\begin{array}{l}\text { Lys } \rightarrow \text { Phe } \\
\text { Phe } \rightarrow \text { His }\end{array}$ & $\begin{array}{l}\mathrm{AAA} \rightarrow \mathrm{TTC} \\
\mathrm{TTC} \rightarrow \mathrm{ATG}\end{array}$ & 7 & 0 & 208.232 & $<.01$ \\
\hline & WT7 & $526-529$ & $\mathrm{His} \rightarrow \mathrm{Arg}$ & $\mathrm{CAC} \rightarrow \mathrm{CGC}$ & 3 & 0 & & - \\
\hline & WT8 & $530-533$ & Leu533 $\rightarrow$ Pro & $\mathrm{CTG} \rightarrow \mathrm{CCG}$ & 2 & 0 & & - \\
\hline & & & & $\mathrm{TTA} \rightarrow \mathrm{TTG}$ & & & & \\
\hline & & & Ser531 $\rightarrow$ Leu & (silent) & & & & \\
\hline & & & Ser531 $\rightarrow$ Trp & $\mathrm{TCG} \rightarrow \mathrm{TTG}$ & & & & \\
\hline
\end{tabular}

katG

$\begin{array}{llllllll}\text { MUT1 } & \text { S315T1 } & \text { Ser } \rightarrow \text { Thr } & \text { AGC } \rightarrow \text { ACC } & 0 & 78 & 2229.57 & <.01\end{array}$

$\operatorname{inh} A$

$\begin{array}{lccccc}\text { MUT1 } & \text { S315T } & \text { Ser } \rightarrow \text { Thr } & \text { TCG } \rightarrow \text { TGG } & 0 & 7 \\ \text { WT } & 315 & & 0 & 1 \\ \text { WT1 } & \text { C15T } & \text { Cys } \rightarrow \text { Thr } & \text { GGC } \rightarrow \text { ACC } & 0 & 6\end{array}$


has enormous implications for TB control programmes. Our findings are comparable with results from a study done in South Africa, which reported a rise in rifampicin monoresistance. ${ }^{45,50}$ A study conducted to evaluate anti-TB drug resistance surveillance in 19 countries reported the presence of rifampicin monoresistance in all of the countries. ${ }^{51} \mathrm{Ri}$ fampicin resistance has often been considered as a surrogate marker of MDR-TB, because it is highly correlated with concomitant isoniazid resistance. ${ }^{47,52}$ In this regard, all patients with rifampicin monoresistance ought to be treated as MDRTB patients. Our findings, however, differed from study findings from Iran and Nigeria, which failed to detect rifampicin monoresistance. ${ }^{53,54}$

We found a high prevalence of mutations in codon 315 , with predominance of the ACC nucleotide sequence in the $k a t G$ gene, which resulted in resistance to both rifampicin and isoniazid. This indicates that the amino acid at position 315 of katG is prone to mutation. These results correspond to what other researchers have reported, and it may be attributable to lifestyle factors, delays or difficulties in accessing health facilities, and patient immunocompromise or noncompliance to treatment. ${ }^{55,56}$ Mutations of the $k a t G$ gene more strongly influence the development MDR-TB than mutations of the inh $A$ gene. ${ }^{57}$

We also observed the presence of rpoB and inhA gene mutations at codon $315(\mathrm{~S} 315 \mathrm{~T})$ and $15(\mathrm{Cl} 15 \mathrm{~T})$ that resulted in resistance to both rifampicin and isoniazid. Our findings are comparable with those of other studies, whereby it has been reported that mutations at the $k a t G-315, r p o B-531$, and inhA-15 positions are associated with high rates of isoniazid-resistant TB. ${ }^{11,27}$ Furthermore, other studies have reported that mutations in codon 315 and the promoter region of the inhA gene are the most common and are associated with isoniazid resistance. ${ }^{14,55}$ These observations suggested that repeated administration of the same anti-TB drugs increases the risk of resistance, including multidrug resistance.

\section{CONCLUSION}

The most frequently detected mutations in our study were the S531L rpoB mutation, the S315T1 katG mutation, and the S315T mutation in the promoter region of the inhA gene. MDR-TB control strategies require an understanding of the evolution of these mutations. Further studies to evaluate these mutations in detail would increase our understanding of the epidemiology and transmission dynamics of drug-resistant M. tuberculosis in Tanzania to inform the planning, design, and implementation of innovative TB control strategies.

Acknowledgements: This study was conducted with financial support from the Ministry of Health, Community Development, Gender, Elderly and Children (MoHCDEC) of Tanzania. The authors acknowledge the logistical support provided by the Kilimanjaro Clinical Research Institute (KCRI) and Kibong'oto Infectious Disease Hospital. We are grateful to the participants for their willingness to take part in the study.

\section{REFERENCES}

1. Khazaei S, Salehiniya H, Soltani S, Mohammadian-Hafshejani A. Multidrug-resistant TB as a major concern for tuberculosis control programs. Iran J Public Health. 2016;45(1):114-115. Medline

2. Patel DM, Patel SD, Jaiswal PS, Brahmbhatt KJ. Drug resistant Mycobacterium tuberculosis and new drug development. Int J Drug Dev Res. 2012;4(2):76-91.

3. Yang $Y$, Zhou $C$, Shi L, Meng H, Yan H. Prevalence and characterization of drug-resistant tuberculosis in a local hospital of Northeast China. Int J Infect Dis. 2014;22:83-86. CrossRef. Medline

4. Jojula M, Ramanama MV, Reddy SR. Prevalence of multidrug-resistant tuberculosis among newly diagnosed cases of sputum-positive pulmonary tuberculosis from MGM Hospital Warangal. Biosci Biotechnol Res Asia. 2013;10(1):475478. CrossRef

5. Muthaiah M, Shivekar SS, Kapalamurthy VRC, Alagappan C, Sakkaravarthy A, Brammachary U. Prevalence of mutations in genes associated with rifampicin and isoniazid resistance in Mycobacterium tuberculosis clinical isolates. $J$ Clin Tuberc Other Mycobact Dis. 2017;8:19-25. CrossRef

6. World Health Organiation (WHO). Global Tuberculosis Report. Geneva: WHO; 2018. https://www.who.int/tb/publications/global_report/en/. Accessed 20 March 2019.

7. Amukoye E. Multi drug resistant tuberculosis: a challenge in the management of tuberculosis. Afr J Health Sci. 2008;15(1):6-13. CrossRef

8. World Health Organiation (WHO). Global Tuberculosis Report. Geneva: WHO; 2014. https://apps.who.int/iris/handle/10665/137094. Accessed 20 March 2019.

9. Floyd K, Falzon D, Getahun H, et al. Use of High Burden Country Lists for TB by WHO in the Post-2015 Era. Geneva: World Health Organization; 2015 https://www.who.int/tb/publications/global_report/high_tb_burdencountrylists2016-2020.pdf. Accessed 20 March 2019.

10. Chonde TM, Basra D, Mfinanga SG, et al. National anti-tuberculosis drug resistance study in Tanzania. Int J Tuberc Lung Dis. 2010;14(8):967-972. Medline

11. Singhal R, Arora J, Sah GC, Bhalla M, Sarin R, Prasad Myneedu V. Frequency of multi-drug resistance and mutations in Mycobacterium tuberculosis isolates from Punjab state of India. J Epidemiol Glob Health. 2017;7(3):175-180. CrossRef. Medline

12. Mohajeri P, Sadri H, Farahani A, Norozi B, Atashi S. Frequency of mutations associated with rifampicin resistance in Mycobacterium tuberculosis strains isolated from patients in West of Iran. Microb Drug Resist. 2015;21(3):315 319. CrossRef. Medline

13. Afanas'ev MV, Ikryannikova LN, I'ina EN, et al. Molecular characteristics of rifampicin- and isoniazid-resistant Mycobacterium tuberculosis isolates from the Russian Federation. J Antimicrob Chemother. 2007;59(6):1057-1064. CrossRef. Medline

14. Van Der Zanden AGM, Te Koppele-Vije EM, Vijaya Bhanu N, Van Soolingen D, Schouls LM. Use of DNA extracts from Ziehl-Neelsen-stained slides for molecular detection of rifampin resistance and spoligotyping of Mycobacterium tuberculosis. J Clin Microbiol. 2003;41(3):1101-1108. CrossRef. Medline

15. Hazbón $M H$, Brimacombe $M$, Bobadilla del Valle $M$, et al. Population genetics study of isoniazid resistance mutations and evolution of multidrug-resistant $\mathrm{My}$ cobacterium tuberculosis. Antimicrob Agents Chemother. 2006;50(8):26402649. CrossRef. Medline

16. Vilchèze $C$, Wang $F$, Arai $M$, et al. Transfer of a point mutation in Mycobacterium tuberculosis inhA resolves the target of isoniazid. Nat Med. 2006;12(9):1027-1029. CrossRef. Medline

17. Puustinen K, Marjamäki M, Rastogi N, et al. Characterization of Finnish Mycobacterium tuberculosis isolates by spoligotyping. J Clin Microbiol. 2003;41(4):1525-1528. CrossRef. Medline

18. Kibiki GS, Mulder B, Dolmans WMV, et al. M. tuberculosis genotypic diversity and drug susceptibility pattern in HIV-infected and non-HIV-infected patients in northern Tanzania. BMC Microbiol. 2007;7:51. CrossRef. Medline

19. van Crevel R, Nelwan RHH, de Lenne W, et al. Mycobacterium tuberculosis Beijing genotype strains associated with febrile response to treatment. Emerg Infect Dis.; $2001 ; 7(5)$ : 880-883. CrossRef. Medline

20. Lawn SD, Mwaba P, Bates M, Piatek A, Alexander H, Ben J, et al. Advances in tuberculosis diagnostics: the Xpert MTB/RIF assay and future prospects for a point-of-care test. Lancet Infect Dis. 2016;13(4):349-361. CrossRef. Medline 
21. loannidis P, Papaventsis D, Karabela S, et al. Cepheid GeneXpert MTB/ RIF assay for Mycobacterium tuberculosis detection and rifampin resistance identification in patients with substantial clinical indications of tuberculosis and smear-negative microscopy results. J Clin Microbiol. 2011;49(8):3068-3070. CrossRef. Medline

22. Ryu YJ. Diagnosis of pulmonary tuberculosis: recent advances and diagnostic algorithms. Tuberc Respir Dis (Seoul). 2015;78(2):64-71. CrossRef. Medline

23. Steingart KR, Henry $M, N g$, et al. Fluorescence versus conventional sputum smear microscopy for tuberculosis: a systematic review. Lancet Infect Dis. 2006;6(9):570-581. CrossRef. Medline

24. Hain Lifescience. GenoType MTBDRplus VER2.0 Instructions for Use (IFU304A-06). Nehren, Germany: Hain Lifescience; 2015. https://www.hain-lifescience.de/include_datei/kundenmodule/packungsbeilage/download. php?id=936. Accessed 20 March 2019.

25. Buyankhishig B, Oyuntuya T, Tserelmaa B, Sarantuya J, Lucero MG, Mitarai S Rapid molecular testing for multi-resistant tuberculosis in Mongolia: a diagnostic accuracy study. Int J Mycobacteriol. 2012;1(1):40-44. CrossRef. Medline

26. Mitarai $\mathrm{S}, \mathrm{Kato} \mathrm{S}, \mathrm{Ogata} \mathrm{H}$, et al. Comprehensive multicenter evaluation of a new line probe assay kit for identification of Mycobacterium species and detection of drug-resistant Mycobacterium tuberculosis. J Clin Microbiol. 2012;50(3):884-890. CrossRef. Medline

27. Sharma SK, Kaushik G, Jha B, et al. Prevalence of multidrug-resistant tuberculosis among newly diagnosed cases of sputum-positive pulmonary tuberculosis. Indian J Med Res. 2011;133(3):308-311. Medline

28. Cox HS, McDermid C, Azevedo V, et al. Epidemic levels of drug resistant tuberculosis (MDR and XDR-TB) in a high HIV prevalence setting in Khayelitsha, South Africa. PLoS One. 2010;5(11): e13901. CrossRef. Medline

29. Sagonda T, Mupfumi L, Manzou R, et al. Prevalence of extensively drug resistant tuberculosis among archived multidrug resistant tuberculosis isolates in Zimbabwe. Tuberc Res Treat. 2014;349141. CrossRef

30. Guerra-Silveira F, Abad-Franch F. Sex bias in infectious disease epidemiology: patterns and processes. PloS One. 2013;8(4):e62390. CrossRef. Medline

31. Ruggieri A, Anticoli S, D'Ambrosio A, Giordano L, Viora M. The influence of sex and gender on immunity, infection and vaccination. Ann Ist Super Sanità. 2016;52(2):198-204. CrossRef. Medline

32. Nhamoyebonde $\mathrm{S}$, Leslie $\mathrm{A}$. Biological differences between the sexes and susceptibility to tuberculosis. J Infect Dis. 2014;209 (suppl 3):S100-S106. CrossRef. Medline

33. Marais BJ, Gie RP, Schaaf HS, et al. The natural history of childhood intra-thoracic tuberculosis: a critical review of literature from the pre-chemotherapy era. Int J Tuberc Lung Dis. 2004;8(4):392-402. Medline

34. Zhang $\mathrm{H}, \mathrm{X}$ in $\mathrm{H}$, Li $\mathrm{X}$, et al. A dose-response relationship of smoking with tuberculosis infection: a cross-sectional study among 21008 rural residents in China. PLoS One. 2017;12(4):e0175183. CrossRef. Medline

35. Günther $G$, van Leth $F$, Alexandru $S$, et al. Multidrug-resistant tuberculosis in Europe, 2010-2011. Emerg Infect Dis. 2015;21(3):409-416. CrossRef. Medline

36. Codlin AJ, Khowaja S, Chen Z, et al. Short report: gender differences in tuberculosis notification in Pakistan. Am J Trop Med Hyg. 201 1;85(3):514-517. CrossRef. Medline

37. Rao S. Tuberculosis and patient gender: an analysis and its implications in tuberculosis control. Lung India. 2009;26(2):46-47. CrossRef. Medline

38. Women's Centre for Health Matters (WCHM). WCHM Position Paper on Gender Sensitive Health Service Delivery. Canberra, Australia: WCHM; 2009 http://www.wchm.org.au/wp-content/uploads/2015/02/WCHM-position-paper-on-gender-sensitive-health-service-delivery.pdf. Accessed 20 March 2019

39. Yamasaki-Nakagawa M, Ozasa K, Yamada N, et al. Gender difference in delays to diagnosis and health care seeking behaviour in a rural area of Nepal. Int J Tuberc Lung Dis. 2001;5(1):24-31. Medline

40. Ting WY, Huang SF, Lee MC, et al. Gender disparities in latent tuberculosis infection in high-risk individuals: a cross-sectional study. PLoS One. 2014;9(11):e1 10104. CrossRef. Medline

41. Karim F, Ahmed F, Begum I, Johansson E, Diwan VK. Female-male differences at various clinical steps of tuberculosis management in rural Bangladesh. Int $J$ Tuberc Lung Dis. 2008;12(11):1336-1339. Medline

42. Feng JY, Huang SF, Ting WY, et al. Gender differences in treatment outcomes of tuberculosis patients in Taiwan: a prospective observational study. Clin Microbiol Infect. 2012;18(9). CrossRef. Medline
43. World Health Organization (WHO). Guidelines for the programmatic management of drug-resistant tuberculosis 2011 update. Geneva: WHO; 2011. https://apps.who.int/iris/bitstream/handle/10665/44597/9789241501583_eng.pdf? sequence=1. Accessed 20 March 2019

44. Horton KC, MacPherson P, Houben RMGJ, White RG, Corbett EL. Sex differences in tuberculosis burden and notifications in low- and middle-income countries: a systematic review and meta-analysis. PLoS Med. 2016;6;13(9):e1002119. CrossRef. Medline

45. Mukinda FK, Theron D, van der Spuy G, et al. Rise in rifampicin-monoresistant tuberculosis in Western Cape, South Africa. Int I Tuberc Lung Dis. 2012;16(2):196-202. CrossRef. Medline

46. Ridzon R, Whitney CG, McKenna MT, et al. Risk factors for rifampin mono-resistant tuberculosis. Am J Respir Crit Care Med. 1998;157(6):1881-1884. CrossRef. Medline

47. Villegas L, Otero L, Sterling TR, et al. Prevalence, risk factors, and treatment outcomes of isoniazid- and rifampicin-mono-resistant pulmonary tuberculosis in Lima, Peru. PLoS One. 2016;1 1(4):e0152933. CrossRef. Medline

48. Jenkins C, Claxton AP, Shorten RJ, McHugh TD, Gillespie SH. Rifampicin resistance in tuberculosis outbreak, London, England. Emerg Infect Dis. 2005;11(6):931-934. CrossRef. Medline

49. Gillespie SH. Evolution of drug resistance in Mycobacterium tuberculosis: clinical and molecular perspective. Antimicrob Agents Chemother. 2002;46(2):267-274. CrossRef. Medline

50. Coovadia YM, Mahomed S, Pillay M, Werner L, Mlisana K. Rifampicin mono-resistance in Mycobacterium tuberculosis in KwaZulu-Natal, South Africa: a significant phenomenon in a high prevalence TB-HIV region. PLoS One. 2013;8(11): e77712. CrossRef. Medline

51. Pablo-Méndez A, Raviglione MC, Laszlo A, et al. Global surveillance for antituberculosis-drug resistance, 1994-1997. World Health Organization-International Union against Tuberculosis and Lung Disease Working Group on anti-tuberculosis drug resistance surveillance. N Engl J Med. 1998;338(23):1641-1649. CrossRef. Medline

52. Jaleta KN, Gizachew M, Gelaw B, Tesfa H, Getaneh A, Biadgo B. Rifampicin-resistant Mycobacterium tuberculosis among tuberculosis-presumptive cases at University of Gondar Hospital, northwest Ethiopia. Infect Drug Resist. 2017;10:185-192. CrossRef. Medline

53. Namaei MH, Sadeghian A, Naderinasab M, Ziaee M. Prevalence of primary drug resistant Mycobacterium tuberculosis in Mashhad, Iran. Indian J Med Res. 2006;124(1):77-80. Medline

54. Otu A, Umoh V, Habib A, Ameh S, Lawson L, Ansa V. Drug resistance among pulmonary tuberculosis patients in Calabar, Nigeria. Pulm Med. 2013;235190. CrossRef. Medline

55. Rahman A, Sahrin M, Afrin S, et al. Comparison of Xpert MTB/RIF assay and GenoType MTBDRplus DNA probes for detection of mutations associated with rifampicin resistance in Mycobacterium tuberculosis. PLoS One. 2016;1 1(4):e0152694. CrossRef. Medline

56. Jian J, Yang X, Yang J. Chen L. Evaluation of the GenoType MTBDRplus and MTBDRs/ for the detection of drug-resistant Mycobacterium tuberculosis on isolates from Beijing, China. Infect Drug Resist. 2018;11:1627-1634. CrossRef. Medline

57. Palomino JC, Martin A. Drug resistance mechanisms in Mycobacterium tuberculosis. Antibiotics (Basel). 2014;3(3):317-340. CrossRef. Medline

\section{Peer Reviewed}

Competing Interests: None decleared.

Received: 20 Dec 2018; Accepted: 12 Mar 2019

Cite this article as: Mgogwe JC, Semvua HH, Safari O, Kapanda GE, Nyombi BM, Chilongola JO. PPrevalence and Distribution of Multidrug-Resistant Mutations in Mycobacterium tuberculosis in Tanzania. E Afr Sci. 2019;1(1):15-22. http://doi.org/10.24248/EASci-D-19-00002.

(C) Mgogwe et al. This is an open-access article distributed under the terms of the Creative Commons Attribution License, which permits unrestricted use, distribution, and reproduction in any medium, provided the original author and source are properly cited. To view a copy of the license, visit http://creativecommons.org/licenses/by/4.0/. When linking to this article, please use the following permanent link: http://doi.org/10.24248/EASci-D-19-00002. 